ARTIGO

\title{
O Brasil e a organização internacional para os refugiados (1946-1952)
}

JOSÉ H. FISCHEL DE ANDRADE*

Rev. Bras. Polit. Int. 48 (I): 60-96 [2005]

\section{Introdução}

Os conflitos travados nas duas guerras mundiais tiveram como resultado, inter alia, a (re)organização político-institucional tanto doméstica, de determinados países, quanto internacional, da comunidade de Estados. Por um lado, e com o término das hostilidades bélicas, novos Estados surgiram, sendo que muitos dos que continuaram a existir passaram a ter regimes políticos distintos dos de antes do enfrentamento armado. Por outro lado, a comunidade internacional passava a ter uma organicidade institucional inexistente no passado, que tomou forma com a criação da Sociedade ou Liga das Nações (Liga) em 1919, e da Organização das Naçōes Unidas (ONU) em 1945.

$\mathrm{Na}$ Agenda, tanto de vários Estados, tomados individualmente, quanto da Liga e da ONU, constava como prioridade um tema recorrente na história da humanidade: os refugiados; i.e. pessoas que, devido a conflito armado ou ao regime político vigente nos seus países de origem, e na impossibilidade de gozarem de proteção nacional, se vêem obrigadas a se dirigir a outros Estados em busca de proteção internacional.

\footnotetext{
* Consultor jurídico do Alto-Comissariado das Naçôes Unidas para os Refugiados (Acnur), Genebra, Suíça (fischel@unhcr.ch). As opiniões expressas são as pessoais do autor e não representam, necessariamente, as da ONU ou do Acnur.
} 
No que respeita à Liga, esta logo se organizou com vistas em possibilitar a proteção, inicialmente, de cerca de dois milhôes de russos que haviam sido desnacionalizados e se encontravam na Europa e na Ásia. Os eventos que tiveram lugar no período entreguerras fizeram com que surgissem vários outros organismos e instrumentos internacionais que visavam, respectivamente, a proteger e a definir o conceito de "refugiados", os quais, por serem perseguidos, se viam compelidos a migrar de seus países (Fischel de Andrade 1996: 6-213; Fischel de Andrade 1999: 75-120). O Brasil, tanto pelo período limitado de participação como membro da Liga, quanto pela dinâmica de sua política interna, não se envolveu nos esforços da comunidade internacional que objetivavam a proteção de refugiados.

Já a ONU encontrou, quando de sua criação, uma situação que superava, numericamente, a vivenciada pela Liga: estima-se que, no período 1939-1947, 53.536.000 pessoas foram deslocadas das suas cidades e países de origem (Ginesy 1948: 70). Com o fim da guerra, a grande maioria dessas pessoas regressou às suas localidades originárias; contudo, havia cerca de um milhão de pessoas que decidiu não regressar. Os motivos que levaram este "milhão restante" - last million, como é conhecido na literatura especializada - a não optar pela repatriação foram, mormente, de cunho político, podendo-se citar, inter alia, a total perda de conexão com seus países de origem, os quais haviam sido anexados por outros ou tiveram instalados, no pós-guerra, novos regimes políticos e sociais (Chen 1973: 164; Bolesta-Koziebrodzki 1962: 156). A controvérsia repatriação $v$ s. reassentamento - este tido como a melhor solução pelas potências ocidentais, aquela desejada pelos países do Bloco do Leste - levou tanto à criação quanto à extinção, no marco da $\mathrm{ONU}$, da Organização Internacional para os Refugiados (OIR).

No plano doméstico, por sua vez, e diferentemente do período entreguerras, o Brasil estabelecera como umas das metas de sua política exterior a participação em várias das atividades empreendidas pela comunidade internacional, deixando claro sua opção por acompanhar, na já iniciada Guerra Fria, os países do Bloco Ocidental. Uma forma de fazê-lo foi inclinar-se a aceitar o reassentamento de refugiados e deslocados de guerra europeus no Brasil. Ao assim proceder, não só se inseria no âmbito de atividades onusianas, como igualmente atraía mão-de-obra 
qualificada para seu território - combinação conveniente de princípios humanitários e expediência política, interna e internacional.

No marco destas considerações iniciais, o objetivo deste trabalho é, primordialmente, resgatar a participação brasileira nas atividades da OIR, assim como a tensão que existia entre, por um lado, as metas de política externa e o desejo da ação humanitária e, por outro lado, a resistência à imigração e a realidade orçamentária e administrativo-burocrática no plano doméstico. Não obstante, nunca se ter tornado Estado-membro deste organismo especializado da ONU, participou o Brasil - de forma retórica, mas ao mesmo tempo ativa - do foro multilateral que buscava uma solução para o problema do "milhão restante", como já indicado na literatura especializada (Silva 1958: 145-8); contudo, a extensão de sua participação ainda não foi objeto de estudo aprofundado. Ao proceder a este resgate histórico, ainda que de modo ilustrativo - sem, portanto, se propor preencher a lacuna existente - pretende-se aportar considerações, fruto de uma experiência pretérita, que possam servir de subsídios aos atores atualmente responsáveis pelo programa de reassentamento que o Brasil tem desenvolvido, de forma ainda experimental (Fischel de Andrade \& Marcolini 2002: 168-76), com o Alto-Comissariado das Nações Unidas para os Refugiados (Acnur), organismo que sucedeu a OIR.

\section{A Organização Internacional para os Refugiados (OIR)}

\section{Marco de surgimento da OIR}

A controvérsia sobre o que deveria ser feito com o "milhão restante"1 levou à criação da OIR, cujo estabelecimento foi objeto de negociações extremamente árduas, resultantes de discussões mormente entre as duas grandes potências, a respeito de seus conceitos ideologicamente diferenciados sobre justiça e liberdade humana. Suas respectivas concepções quanto à relação que deveria existir entre o indivíduo e o Estado confrontavam-se forte e vividamente, de modo que se pode asseverar terem as negociações

\footnotetext{
${ }^{1}$ A composição deste "milhão" era aproximadamente de 275.000 poloneses, 200.000 judeus, 200.000 espanhóis, 190.000 lituanos, latislavos e estonianos, 150.000 iugoslavos - tanto sérvios quanto croatas -, e 100.000 ucranianos; cf. Stoessinger 1956: 55-58.
} 
para a criação da OIR, marcado a transição entre as esperanças de uma colaboração eficaz no cenário pós-guerra e a realidade da Guerra Fria.

No âmbito da ONU, a questão dos refugiados e dos deslocados fora trazida à baila já quando da primeira reunião de sua Assembléia Geral, realizada em Londres, de 10 de janeiro a 14 de fevereiro de 1946. No dia 12 de fevereiro, a Assembléia Geral adotou uma Resolução que recomendava o estabelecimento de um Comitê Especial para preparar um relatório, a ser examinado na primeira sessão do Conselho Econômico e Social (Ecosoc), e na segunda parte da primeira Sessão da Assembléia Geral, a ser realizada no fim do segundo semestre daquele mesmo ano, por reconhecer a urgência imediata de solucionar o problema dos refugiados e dos deslocados, além da necessidade imperiosa de distingui-los dos criminosos de guerra, espiões e traidores.

O Comitê Especial, estabelecido a 16 de fevereiro de 1946, sob a denominação de Comitê Especial de Refugiados e Deslocados, reuniuse em Londres, de 8 de abril a $1^{\circ}$ de junho do mesmo ano, e, depois de descentralizar-se em quatro subcomitês, decidiu pela necessidade de ser criado um órgão internacional que cuidasse do problema dos refugiados e dos deslocados. Após vários meses de trabalho, o (Ecosoc) a 3 de outubro, aprovou o Projeto de Constituição da OIR, em face dos comentários críticos dos Estados-membro das Naçōes Unidas, encaminhando-o então à Assembléia Geral (Zanotti 1948: 96-7).

A Assembléia Geral, que realizou a segunda parte de sua primeira sessão em Nova York, de 23 de setembro a 15 de dezembro de 1946, remeteu ao seu Terceiro Comitê todas as discussões havidas, sendo que finalmente, no último dia da Sessão da Assembléia, a Constituição da Organização Internacional para os Refugiados (Constituição da OIR) foi votada, tendo sido objeto de 18 abstençóes (dentre elas a do Brasil), trinta votos a favor e cinco contra (Holborn 1956: 45; Yundt 1988: 32; Gordenker 1987: 25; Bolesta-Koziebrodzki 1962: 158; Ruiz de Santiago 1989: 235).

O resultado dessa votação foi significativo, tanto pelas abstençōes quanto pelos votos contra. As abstenções podem ser vistas como uma falta de interesse pelo problema dos refugiados, em especial se se levar em conta que somente dois dos Estados que se abstiveram da votação eram europeus (i.e. Tcheco-Eslováquia e Suécia). Já os votos contrários foram 
conseqüência tanto da discordância do Bloco socialista com o texto da Constituição da OIR, quanto do seu desejo de manter a problemática dos refugiados fora da Agenda internacional. A votação, portanto, refletiu a criação de uma organização que, apesar de originalmente ter como escopo propósitos humanitários, já exibia muitas características de natureza essencialmente política.

Não obstante a repulsa da URSS e seus satélites pela Constituição da OIR, não se pode negar a influência que esta recebeu das sugestôes e propostas daqueles. Apesar de ter a grande maioria de suas emendas recusadas (Ginsburgs 1957: 350-1), os Estados do Bloco do Leste lograram incorporar na Constituição da OIR repetidas e insistentes menções à repatriação e ao pronto retorno (early return) dos deslocados aos seus países de origem, assim como amplas cláusulas de cessação e de exclusão.

As dificuldades político-ideológicas já presenciadas desde os trabalhos preparatórios da Constituição da OIR sugeriam que, provavelmente, não seria tão fácil chegar-se ao número necessário de comprometimentos, por meio de instrumentos de adesão ou ratificação, que possibilitasse à OIR o início de suas atividades.

Devido à premência de se centralizar o trabalho de proteção e de assistência aos refugiados e aos deslocados, sob a égide das Nações Unidas, e de se manter esse tema na Agenda internacional, conclui-se, no mesmo dia em que se aprovou a Constituição da OIR, o Acordo sobre Medidas Provisórias a serem tomadas concernentes aos Refugiados e Deslocados (Acordo de 1946). O Acordo de 1946 deveria entrar em vigor imediatamente quando do recebimento do oitavo documento de assinatura por parte de um Estado signatário da Constituição da OIR, o que aconteceu a 31 de dezembro de 1946.

\section{Comissão Preparatória da OIR}

O Acordo de 1946 estabelecia a Comissão Preparatória para a Organização Internacional para os Refugiados (Comissão Preparatória), a qual deveria assegurar a continuidade no trabalho atinente aos refugiados e aos deslocados durante o período que se estenderia entre o término das atividades do Comitê Intergovernamental para os Refugiados 
(Comitê Intergovernamental) e da Administração das Nações Unidas para o Socorro e a Reconstrução (UNRRA) ${ }^{2}$, previsto para meado de 1947, e a existência oficial da OIR, que dependia do recebimento de 15 instrumentos de comprometimento - i.e. de ratificação ou adesão.

A entrada em vigor do Acordo de 1946 teve como conseqüência a criação imediata da Comissão Preparatória, que passou a existir neste mesmo 31 de dezembro de 1946 (Bolesta-Koziebrodzki 1962: 158; Heuven Goedhart 1953: 275; Zanotti 1948: 103). Como o Acordo de 1946 estipulava que a primeira sessão da comissão deveria ser convocada tão logo quanto possível, reuniu-se esta em fevereiro de 1947, com vista em dar início à preparação do trabalho da OIR (Reut-Nicolussi 1948: 46).

A Comissão Preparatória era composta de um secretariado executivo, auxiliado por um consultor jurídico, e ao qual eram subordinados secretariados de saúde, custódia e manutenção, de administração e orçamento, e de repatriação e reassentamento, todos com subseções (Rio Branco 1949c: 3). Assumiu a Comissão Preparatória, a proteção de 704.000 refugiados e deslocados, quase todos espalhados pela Alemanha, Áustria, Itália e Oriente Médio, tendo aceitado também a responsabilidade pela proteção dos interesses de outros refugiados e deslocados elegíveis para reassentamento, que totalizavam cerca de 900.000, sendo que 350.000 encontravam-se nas zonas ocupadas pelos Aliados, e 550.000 estavam distribuídos nos demais países europeus (Lobo 1948: 3).

Os primeiros seis meses de existência da Comissão Preparatória foram deveras burocráticos. Foi somente com o término das funçōes do Comitê Intergovernamental e da UNRRA, que a Comissão Preparatória pôde, em $1^{\circ}$ de julho de 1947 , assumir as responsabilidades e as atividades operacionais destes dois organismos (Grahl-Madsen 1966: 18; Balogh 1949: 431; Goodwin-Gill 1996: 129), o que a tornou a maior organização em operação das Nações Unidas, tanto no âmbito geográfico

\footnotetext{
2 Tanto o Comitê Intergovernamental, fundado a 14 de julho de 1938, quanto a UNRRA primeira organização internacional a incorporar as palavras "Nações Unidas" em seu nome -, cujo acordo de criação foi assinado a 9 de novembro de 1943, foram estabelecidos, seguindo sugestão estadunidense, como alternativas à incapacidade operacional da Liga. Para uma análise destes dois organismos internacionais, v. Fischel de Andrade 1996: 102-107 e 107-110, respectivamente.
} 
de atividades, quanto no número de pessoas empregadas. Isso feito, pôde ela concluir uma série de acordos bilaterais - como o que veio a ser firmado com o Brasil, infra - e multilaterais, que versavam, inter alia, sobre o estabelecimento dos escritórios de representação e outras instalações no Estado contratante, sobre os privilégios e imunidades da Organização e de seu pessoal, e sobre as condições nas quais o reassentamento seria processado.

O fato de a Comissão Preparatória ter gozado de plena capacidade jurídica fez com que, quando a OIR entrasse em funcionamento, em 1948, boa parte do trabalho já tivesse sido realizada (Miaja de la Muela 1952: 137). Deve-se mencionar que ela não se ateve aos europeus, tendo mesmo assistido aos chineses que haviam sido deportados pelos japoneses de seus assentamentos, no retorno aos seus domicílios em Singapura, Sião e nas Índias Holandesas, o que foi levado a cabo após as permissões dos respectivos governos.

\section{Entrada em vigor da Constituição da OIR}

A Constituição da OIR entrou em vigor somente a 20 de agosto de 1948 (Balogh 1949: 432; Goodwin-Gill 1996: 129; Gordenker 1987: 25; Bolesta-Koziebrodzki 1962: 158), tendo como conseqüência o término das atividades da Comissão Preparatória. A substituição desta pela OIR teve importante efeito financeiro na execução dos trabalhos em prol dos refugiados, porquanto, durante a fase inicial, a Comissão Preparatória recebeu tão-somente adiantamentos posteriormente dedutíveis das colaborações, que seriam devidas quando a OIR entrasse em pleno funcionamento. No campo operacional, contudo, não se testemunhou qualquer alteração, podendo-se afirmar que a entrada em vigor da Constituição da OIR não ensejou mudanças práticas no trabalho executado, tendo sido, portanto, somente nominal (Weis 1954: 210).

Apesar de ter sido vislumbrada a possibilidade de se estabelecer a sede da OIR em Paris, optou-se por Genebra para sediá-la - não obstante o início de suas atividades ter-se dado em Lausanne. Após os 15 Estados que ensejaram, por meio de seu comprometimento com a Constituição da OIR, a existência deste organismo, somente três ratificaram ou aderiram à $\mathrm{OIR}$, de sorte que durante suas atividades, ela não teve mais que 18 
Estados-membro (Ruiz de Santiago 1989: 235; Bolesta Koziebrodzki 1962: 158; Gordenker 1987: 25; Stoessinger 1956: 145). O gozo de personalidade jurídica, assim como do status de entidade especializada da ONU, possibilitou à OIR estruturar sua própria política quanto à admissão de Estados-membros, o que lhe ensejou ter tanto uma operacionalidade sem a participação dos Estados do Bloco do Leste, quanto, como Estados-membro, países não tecnicamente vinculados às Naçōes Unidas, caso da Suíça.

Mesmo havendo possibilitado a participação de Estados que não fossem membros das Nações Unidas, o limitado número de países que participaram na OIR comprometeu seriamente seu orçamento, cujas colaboraçóes haviam sido divididas, na esperança e confiança de que todos os Estados-membro das Nações Unidas se vinculariam à OIR. Apesar de ter tido um orçamento real três vezes maior que o da ONU, e um quadro de pessoal tão numeroso quanto o desta Organização, os poucos Estados-membro fizeram com que a OIR fosse a menos universal das entidades especializadas, sendo, portanto, por um lado, uma das menores organizações das Nações Unidas e, por outro, a maior; a OIR despunha de 2.659 funcionários internacionais, de uma frota de 3.900 veículos, e da utilização de 39 navios, que possibilitavam o transporte de 37.500 passagueiros (Moussalli 1992: 86).

\section{Estrutura interna \& funções}

A OIR estabeleceu, como principais órgãos internos, um Conselho Geral, responsável pela determinação das políticas (policy-making) a serem adotadas pela Organização, a cujas reuniōes cada Estado-membro deveria enviar um representante (a primeira foi realizada a 13 de setembro de 1948, tendo o representante brasileiro participado na condição de observador); um Comitê Executivo, ao qual estavam incumbidas as funções necessárias à implementação das políticas estabelecidas pelo Conselho Geral, sendo este composto pelos representantes de nove Estados-membro da OIR; e uma administração, cujo diretor-geral devia levar a cabo as funções administrativas e executivas definidas pelos dois órgãos mencionados, perante os quais ele se responsabilizara. Posto administrativo mais alto, equivalente ao dos Altos Comissários existentes 
durante o período entreguerras, o cargo de diretor-geral foi ocupado pelo Sr. William H. Tuck e, posteriormente, a partir de junho de 1949, pelo seu compatriota estadunidense Sr. Donald G. Kinsley, devendo-se mencionar que este se posicionou contra a intenção de seu governo em extinguir a OIR, tendo em repetidas ocasióes recomendado a extensão da existência deste organismo - o cargo equivalente ao de direitor-geral fora ocupado, na Comissão Preparatória, por outro estado-unidense, o Sr. Arthur Altmayer (Stoessinger 1956: 145-6).

A Constituição da OIR definiu pormenorizadamente quais seriam as funções a serem desempenhadas, a saber: repatriação; identificação, registro e classificação; auxílio e assistência; proteção jurídica e política; transporte; e reassentamento.

Ademais das tarefas principais, anteriormente citadas, impõe-se mencionar as atividades que a OIR executou junto à administração dos campos de refugiados e de deslocados (Cuadra 1970: 151) e junto à localização dos desaparecidos. Quanto a esta, optou-se por se estabelecer, em Alrosen, Alemanha, em janeiro de 1949, um Serviço Internacional de Buscas (International Tracing Service) que, aproveitando os arquivos do Escritório Central de Buscas, estabelecido em 1945 pelas quatro Forças de Ocupação, sob a égide da UNRRA, foi capaz de localizar parentes, reunir famílias e estabelecer o destino de desaparecidos, sendo que para isso tinha um índice de mais de 6.000.000 de nomes. Este Serviço Internacional de Buscas auxiliou deveras a OIR no que respeita aos processos de indenização e de restituição que refugiados e deslocados moveram contra os governos da Alemanha e da Áustria.

\section{Mandato ratione personae}

A Constituição da OIR estampava uma definição de "refugiado" muito mais ampla que as anteriores e, ademais, colocava sob seu mandato, igualmente, os deslocados, jamais definidos em instrumentos jurídicos convencionais.

A complexidade das cláusulas conceituais foi resultado de uma tentativa de reconciliar os pontos de vista divergentes que os Estadosmembro externaram numa infinidade de órgãos e comitês que participaram do longo processo - cerca de 18 meses - de redação da Constituição da OIR (Hathaway 1984: 374). Como conseqüência deste intrincado 
processo de preparação, as definiçõoes contidas na Constituição da OIR caracterizaram-se por ser uma mistura de conceitos geográficos ou pragmáticos e ideológicos (Hartling 1979: 127), o que fez com que se afirmasse que, por elas serem consideravelmente artificiais e formalísticas, foram completamente desconsideradas quando de sua aplicação (Fowler 1974: 124).

Essa visão um tanto pessimista não deve prevalecer quando do estudo da conceituação dos refugiados e dos deslocados sob o mandato da OIR. Com efeito, muitos foram os avanços trazidos pelas cláusulas de inclusão estampadas na Constituição da OIR, devendo-se destacar, em especial, a individualização do conceito de refugiado e a descrição das razões de sua perseguição.

Quanto à perspectiva individualista da definição de refugiado, tem-se que o aspecto coletivo deixou de ser decisivo na concessão do status de refugiado, tendo sido a ênfase posta na situação do indivíduo. Isso trouxe como conseqüência imediata e fundamental a necessidade de se estabelecer um procedimento de elegibilidade individual que o protegesse de toda e qualquer arbitrariedade, a qual o pudesse privar tanto do reconhecimento como refugiado bona fide, quanto dos benefícios decorrentes deste reconhecimento (Aga Kahn 1976: 297).

Com uma redação que desenvolvia a perspectiva individualista de forma muito mais avançada que o Comitê Intergovernamental e a UNRRA, a OIR chegou bastante perto de adotar um esquema de determinação puramente subjetivo, a partir do momento em que considerou como admissíveis (eligible) pessoas que, fora de seu país de nacionalidade, expressassem objeções válidas de a ele retornar, sendo suficiente que as opiniōes políticas do refugiado o levassem a não desejar se valer da proteção de seu país de origem - o estabelecimento do critério "objeçôes válidas" e de seu respectivo conteúdo, contudo, ficou longe de ser o resultado de um entendimento unânime (Hathaway 1984: 374, 378). Essa cláusula, considerada uma das mais amplas da jurisdição da OIR, incluía pessoas desde os "russos brancos" e armênios que se negavam a ser repatriados até os provenientes de países comunistas estruturados no período imediatamente pós-guerra.

Outro avanço trazido pela conceituação de "refugiado" foi a menção de perseguição e do seu respectivo bem fundamentado temor. $\mathrm{O}$ fato - 
não só de descrever as razões que faziam de uma pessoa um refugiado, mas também de associar tais razões a um elemento parcialmente subjetivo, nomeadamente, o temor - fez com que todo refugiado tivesse que justificar o temor invocado por meio de sua comprovação, a qual se deveria dar por meio de provas baseadas tanto em fatos objetivos, quanto nos fatores pessoais que o faziam temer perseguição, no presente ou no futuro, mesmo não tendo ele sido perseguido no passado.

\section{Término das atividades}

O caráter contínuo do problema dos refugiados prevaleceu sobre a natureza temporária da OIR. Apesar de não ter concluído todas as tarefas a ela designadas, a OIR foi a primeira entidade especializada das Nações Unidas a ser extinta, fato que não deixou de ser considerado prematuro (Aga Khan 1976: 186).

As competências da OIR foram transferidas para os Estados onde havia refugiados em seus territórios e para outras organizações. Os países, onde os refugiados se encontravam, não se mostravam muito ansiosos em assumir a responsabilidade que lhes recaía em razão de seu posicionamento geográfico, a qual, sustentavam eles, era da comunidade internacional. Essa transferência de responsabilidade pelos refugiados, de uma organização internacional para governos nacionais, foi de encontro ao conceito lógico da relação entre a sociedade internacional e o refugiado, porquanto somente quando a responsabilidade conjunta é reconhecida e transformada em ação pode o problema dos refugiados ser resolvido satisfatoriamente (Heuven Goedhart 1953: 358).

Já no que respeita aos organismos internacionais governamentais, além do Acnur - o qual herdou, no plano global, a maior parte das funções da OIR - outro organismo, esta já no âmbito regional, que teve importância quando da extinção da OIR foi o Comitê Intergovernamental para as Migraçôes Européias (Perruchoud 1989: 501-17). Tendo-se ocupado inclusive de refugiados sob o mandato do Acnur, este Comitê Intergovernamental para as Migraçóes Européias - que, como seu próprio nome sugere, se restringiu ao reassentamento de refugiados e aos deslocamentos dos excedentes de população européia - foi o resultado do desejo do Congresso estadunidense em estabelecer um organismo 
responsável pelos refugiados fora do âmbito da ONU; isso porque não aceitava ele a criação de um órgão que tivesse representantes dos países do Bloco do Leste. Por fim, as organizações não-governamentais, quando informadas da primeira data de extinção da OIR, postergada algumas vezes, informaram a esta organização que não estavam em condições de assumir toda a responsabilidade pela assistência e proteção dos refugiados.

Por não haver a OIR cessado suas atividades no mesmo momento em que deixou de existir, até mesmo a literatura especializada não chega a um entendimento com relação a essas duas datas. Ao que tudo indica, a OIR, que, em um primeiro momento deveria ser extinta a 30 de junho de 1950 (Balogh 1949: 451-2), concluiu suas atividades operacionais não em fins de 1951 (Krenz 1966: 113), às vésperas da entrada em vigor do mandato do Acnur, mas, sim, em janeiro de 1952 (Grahl-Madsen 1966: 18; Heuven Goedhart 1953: 349), mais precisamente no dia 31 (Bolesta Koziebrodzki 1962: 159), tendo sido extinta tão-somente no mês seguinte (Stoessinger 1956: 154), a 28 de fevereiro (Goodwin-Gill 1996: 129).

\section{O Brasil e a OIR: política externa e política imigratória}

\section{Contextualização da política imigratória brasileira ao término da Segunda Grande Guerra}

No ano de 1945, tão-só 3.168 estrangeiros imigraram para o Brasil (Neiva 1949: 22). Ao findar a Segunda Grande Guerra, a realidade imigratória no Brasil era, portanto, consideravelmente distinta da que prevalecera desde fins do século XIX: no decênio 1881-1890, o número de imigrantes foi de 451.700; no decênio 1891-1900, 362.606; no decênio 1901-1910, 77.914 (diminuição resultante da supressão de auxílio ao transporte de imigrantes); no decênio 1911-1920, 100.312 (cifra que não foi superior em razão da Primeira Grande Guerra); no decênio 1921-1930, 203.822; e no decênio 1931-1940, chegaram tãosomente 22.282 imigrantes (Ribeiro 1943: 60), equivalentes tão-só a $11 \%$ do decênio imediatamente anterior.

Notam-se, pois, alteraçóes consideráveis quanto às cifras ao longo das décadas. A que chama mais atenção é a abrupta redução na década 
de 1930, que se deve à política restritiva de imigração iniciada, no Estado Novo, que chegou a proibir totalmente a imigração. Pouco depois se introduziu o regime de quotas, pela Constituição de 1934, e, no mesmo ano, mais restrições. No marco da Constituição de 1937, igualmente restritiva, criou-se o arcabouço jurídico da política imigratória e de estrangeiros brasileira, que cuidava da entrada, da nacionalidade, da extradição, da expulsão, e das reformas do Departamento de Povoamento, que passou a ser o Departamento Nacional de Imigração, e do Serviço de Irrigação, Reflorestamento e Colonização, que se tornou a Divisão de Terras e Colonização. Por fim, o Decreto-Lei n ${ }^{\circ} 3.175$, de 7 de abril de 1941, suspendeu a corrente imigratória para o Brasil.

No final da Segunda Grande Guerra, após 15 anos, portanto, de implementação de uma política que ia de encontro ao histórico da política imigratória nacional, as autoridades consideraram a vinda de refugiados e deslocados de guerra, na condição de imigrantes, para o Brasil. A mudança do regime político em outubro de 1945, seguida das eleições de 2 de dezembro de 1945, e da posse de Eurico Gaspar Dutra, a 31 de janeiro de 1946, propiciou uma abertura na política imigratória, que só não teve mais resultados porque, não obstante ter mudado o regime, a grande maioria dos funcionários do segundo e terceiro escalóes mantiveram-se nas suas funções, tendo sido muitos deles, por três lustros, doutrinados por uma política deveras restritiva (Lesser 2003: 277-87; Bertonha 1997: 106-30).

\section{Primeiros Passos}

Quando, em 1946, o Comitê Especial do Ecosoc ocupou-se do tema dos refugiados e deslocados de guerra (supra), o Brasil participou ativamente de suas deliberações. $\mathrm{O}$ delegado brasileiro indicava, no que seria uma de suas primeiras intervenções naquela instância, que recebera grande quantidade de cartas de refugiados desejosos de ir ao Brasil, e, portanto, solicitava ao Comitê Intergovernamental e à UNRRA o nome das pessoas que queriam imigrar, assim como suas respectivas informaçôes e dados pessoais (Exposé 1946a: 1).

Junto ao Subcomitê de Definições do Comitê Especial, na sessão de 16 de abril de 1946, o delegado brasileiro sustentava que o Brasil poderia dar uma "ajuda real, uma colaboração eficaz" quanto ao 
reassentamento, colaborando, portanto, para se atingirem os resultados humanitários então buscados, e podendo receber em seu território um "grande número" de refugiados e deslocados (Exposé 1946b: 1). Ao fazê-lo, comentou o delegado brasileiro que o Brasil já possuía, na seara imigratória, mais de um século de experiência, durante o qual chegaram ao país cerca de cinco milhões de imigrantes. Contudo, destacou, esta experiência levava à busca de elementos assimiláveis à formação étnica, econômica e social brasileira, o que significava que "não [se] quer[ia] reincidir no erro de admitir, por exemplo, japoneses, que mostraram ser inassimiláveis, sem falar de outros inconvenientes os quais não há a necessidade de recordar” (Exposé 1946b: 2) ${ }^{3}$. No mesmo tom, asseverou “[n] ós queremos de preferência ( $p l u t o ̂ t)$ reforçar nossa ascendência européia, após uma escolha tão rigorosa quanto possível. Esta é a primeira condição que deve colocar o Brasil, pátria nova que já tem um passado honroso e digno, mas que apresenta acima de tudo um futuro cheio de promessa" (Exposé 1946b: 2). Em seguida, esclarecia o delegado brasileiro que os trabalhadores que desejassem se estabelecer nas cidades não seriam de interesse brasileiro, pois se tem "a preocupação de proteger o trabalhador nacional contra a eventualidade de uma concorrência possível” (Exposé 1946b: 2).

Pouco mais tarde, no Subcomitê de Documentação do Comitê Especial, o delegado brasileiro já reiterava que, como condição geral, ao Brasil só deveriam se dirigir, de forma espontânea ou organizada, imigrantes que fossem agricultores, técnicos ou trabalhadores qualificados (Renseignements 1946: 2). Desde o início, portanto, deixavam claro os representantes brasileiros o condicionamento da moção humanitária à satisfação da conveniência e necessidade domésticas.

Descuidando da precisão, e correndo o risco de criar expectativas que poderiam não ser - como efetivamente não foram - satisfeitas, afirmou-se que o Brasil poderia receber de 100.000 a 200.000 imigrantes por ano, que ajudariam na tarefa de povoar e desenvolver as riquezas nacionais (Renseignements 1946: 7-8).

\footnotetext{
${ }^{3}$ Mesmo se se abstrair o contexto da época, que tinha o Japão como um dos países do Eixo derrotados no conflito que há pouco se findara, é inquietante a afirmação discriminatória do delegado brasileiro, em especial se se considerar que, de 1884 a 1941, os japoneses constituíam o quarto maior contingente de imigrantes que se dirigiram ao Brasil, ficando atrás somente dos italianos, portugueses e espanhóis (nesta ordem), e à frente, portanto, das demais 67 nacionalidades então registradas; cf. Ribeiro 1943: 61-2.
} 
O desempenho retórico da delegação brasileira no Comitê Especial, e nos seus subcomitês, chamou a atenção dos responsáveis pelo reassentamento de refugiados e deslocados. Tanto que, quando em viagem aos Estados Unidos, em maio de 1946, o presidente Dutra e seu ministro João Alberto Lins de Barros foram procurados pelo Departamento de Estado, que lhes sondou sobre a possibilidade real de o Brasil receber refugiados e deslocados, entre os milhares que existiam nessas condições na Europa, e que estavam a cargo do Comitê Intergovernamental. Como este se responsabilizaria por todas as despesas de transporte dos imigrantes até o porto brasileiro de desembarque, que poderia ser feito pela metade do preço no Duque de Caxias, o que fora aquiescido pelo Ministério da Marinha, a proposta era de imensa vantagem para o Brasil (Neiva 1949: 22-3). Em julho de 1946, chegou ao Rio de Janeiro uma missão do Comitê Intergovernamental, com o objetivo de coletar dados e verificar a factibilidade de os refugiados e deslocados serem, efetivamente, reassentados no Brasil.

No plano multilateral, por sua vez, e com vistas em satisfazer um dos requerimentos necessários ao reassentamento dos refugiados e deslocados, concluía-se, a 15 de outubro de 1946, o Acordo Relativo à Emissão de um Documento de Viagem para Refugiados que sejam da Competência do Comitê Intergovernamental para os Refugiados (Acordo sobre Documento de Viagem), assinado por 23, ratificado por 21, aceito formalmente por outros 12 Estados (Vulkas 1972: 157; Heuven Goedhart 1953: 285; Weis 1954: 206), e reconhecido de facto pelas autoridades da maioria dos países. Dentre estes incluía-se o Brasil, que, apesar de ter assinado ad referendum o Acordo sobre Documento de Viagem em novembro de 1947, reconheceu desde logo (Yundt 1988: 36-37), por cônsules brasileiros, o título de viagem expedido, ainda que somente em casos excepcionais (Carneiro 1967a: 575). Apesar de a aprovação parlamentar ter ocorrido em 22 de julho de 1949 (Decreto Legislativo $\mathrm{n}^{\mathrm{O}} 21$ ), e de o depósito do instrumento de ratificação, por parte do Brasil, só ter sido feito a 6 de maio de 1952 (Chermont 1952), foi somente a 7 de outubro de 1955, nove anos após a conclusão do Acordo sobre Documento de Viagem, que o Decreto $n^{\circ} 38.018$, de promulgação, foi publicado.

Paralelamente às negociaçóes entre o governo brasileiro e o Comitê Intergovernamental, que seguiam seu lento curso burocrático, o presidente 
Dutra decidira pelo envio de três comissões de seleção à Europa, a serem constituídas por um chefe, um funcionário indicado pelo Ministério do Trabalho, um cônsul, um médico, um secretário e um intérprete (CIC 1955: 29-30). Em fins de outubro, o grupo de seleção brasileiro já se encontrava a caminho da Europa ${ }^{4}$, sem ter levado consigo, contudo, instruções quanto aos critérios de seleção dos refugiados e deslocados, nem tampouco o cadastro da mão-de-obra necessitada no Brasil. No que respeita a este, não obstante o artigo 97 do Decreto-Lei no 7.967, de 18 de setembro de 1945, rezar que "O Conselho de Imigração e Colonização procederá, dentro do prazo de noventa dias, ao cadastro da mão de obra que deixa ser suprida mediante a introdução de imigrantes (...)", o cadastro jamais foi feito. Sua utilização, por parte dos selecionadores brasileiros, teria sido, indubitavelmente, de significativa valia.

Quanto aos critérios a serem utilizados quando da seleção dos refugiados e deslocados, foram eles elaborados in loco pelo então chefe das comissões de seleção e conselheiro do Conselho de Imigração e Colonização (CIC), sr. Artur Hehl Neiva. Após pouco mais de três meses de trabalho na Europa, enviava ele longo relatório, de cerca de duzentas páginas, a 6 de fevereiro de 1947, onde expunha, ademais de consideraçôes sobre as concentrações de refugiados e deslocados que potencialmente poderiam se dirigir ao Brasil, sugestóes quanto aos grupos nacionais que deveriam ser selecionados, assim como os respectivos critérios a serem utilizados. Recomendava o conselheiro Neiva a vinda, nesta ordem de prioridade, de baltas (lituanos, letôes e estonianos), ucranianos, poloneses, russos brancos (não comunistas) e iugoslavos (Neiva 1949: 42). Dois anos após o relatório do sr. Neiva, ainda se esboçavam as instruçôes a serem observadas quanto à definição de refugiado, ao regime legal de entrada no Brasil, às categorias de refugiados, ao regime de seleção, e às comissões de seleção (Rio Branco 1949a: 1-8).

A $1^{\circ}$ de abril de 1947, era concluído em Londres, no plano bilateral, o Acordo entre o Governo dos Estados Unidos do Brasil e

\footnotetext{
${ }^{4}$ As missões brasileiras de seleção foram as primeiras a se operacionalizarem na Europa. Contudo, sua composição nunca chegou a ser completa, como inicialmente vislumbrado: entre os vários problemas havidos, a segunda missão nunca chegou a ter um médico designado após a exoneração do primeiro, houve só um chefe e um médico para toda a Alemanha, e apenas um chefe para a Áustria; cf. Lobo 1948: 7.
} 
o Comitê Intergovernamental de Refugiados (Acordo Brasil-Comitê Intergovernamental), mediante o qual o Brasil se comprometia a receber um primeiro grupo, a título de experiência, de mil famílias, não devendo exceder o total de cinco mil indivíduos, sendo que o número de celibatários em cada grupo não deveria ultrapassar $40 \%$. Sendo satisfatórios os resultados da imigração deste primeiro grupo experimental, o governo brasileiro se dispunha a concluir um acordo para a imigração de um número mais elevado de pessoas. Segundo o Acordo Brasil-Comitê Intergovernamental, ao Brasil caberia o pleno direito de seleção e a responsabilidade pela recepção, encaminhamento e colocação profissional dos imigrantes, sendo que todas as despesas decorrentes do transporte, assim como os meios deste, seriam de incumbência do Comitê Intergovernamental, ao qual caberia, igualmente, a contribuição, com até cem mil dólares americanos, para as despesas de melhoramento das condiçôes de recebimento e de estabelecimento de centros de orientação. Ademais, no marco daquele instrumento internacional, combinou-se que o Comitê Intergovernamental nomearia uma pessoa de nacionalidade brasileira como seu representante residente no Rio de Janeiro, cidade na qual se encontraria a sede da Comissão Especial do Comitê Intergovernamental para o Brasil, a Argentina, o Paraguai e o Uruguai.

Logo após a assinatura do Acordo Brasil-Comitê Intergovernamental, chegava, a 16 de maio de 1947, o primeiro grupo de refugiados e deslocados. Um lamentável jogo de interesses, intriga, deselegância éticoprofissional e sabotagem sistemática, levado a cabo por membros do CIC, levaria à exoneração, a $1^{\circ}$ de agosto de 1947 , do chefe das comissões de seleção, o que teria se justificado com base em levianas alegações de má seleção no tocante tanto à parte de saúde quanto à profissional dos selecionados (Neiva 1949: 7-117). O reassentamento dos refugiados e deslocados já era objeto de acalorado debate também nos meios de comunicação, onde se faziam tanto o ataque quanto a defesa (Queiroz 1947; Lins do Rego 1947; Lacerda 1947) da nova política imigratória (RSP 1947: 57-70) e humanitária do Brasil. 


\section{O envolvimento do Brasil na comissão preparatória da OIR}

Apesar de o Acordo de 1946 ter entrado em vigor a 31 de dezembro de 1946, e de sua primeira reunião ter tido lugar em fevereiro de 1947, a Comissão Preparatória - que deveria operacionalizar temporariamente as atividades que viriam a ser da incumbência da OIR após a entrada em vigor de sua Constituição - só passou a funcionar na prática em julho de 1947, quando assumiu as responsabilidades e as atividades operacionais do Comitê Intergovernamental e da UNRRA (supra).

No mesmo dia em que a Comissão Preparatória tornou-se efetivamente operacional, a $1^{\circ}$ de julho de 1947, o Brasil assinou a Constituição da OIR, indicando que desejava colaborar e comprometerse, formal e posteriormente, mediante instrumento de ratificação. A assinatura da Constituição da OIR possibilitou ao governo brasileiro participar, ativamente, nas reuniões da Comissão Preparatória, na sua sede, em Genebra.

Naquele mesmo dia, o chefe executivo no Brasil da Comissão Preparatória escrevia sua primeira correspondência ao presidente do CIC, informando formalmente que o Comitê Intergovernamental fora extinto em 30 de junho de 1947 e que a Comissão Preparatória assumira suas responsabilidades, inclusive as relativas à implementação do Acordo Brasil-Comitê Intergovernamental, assinado em $1^{\circ}$ de abril de 1947 (Carvalho 1947a). Algumas semanas depois, contudo, informava o chefe executivo da Comissão Preparatória que, por estar iniciando uma nova contabilidade, só assumiria o reembolso das despesas já havidas no marco do Acordo Brasil-Comitê Intergovernamental, e não das em haver (Carvalho 1947b).

O delegado brasileiro junto à Comissão Preparatória em Genebra, ministro Helio Lobo, que chegou a ser seu vice-presidente, foi uma das autoridades nacionais mais dedicadas à vinda de refugiados e deslocados ao Brasil. No marco daquela instância, fazia, com suas declaraçôes, que o Brasil viesse a ser o primeiro país a planejar, já para janeiro de 1948, o reassentamento de refugiados e deslocados, particularmente da Áustria, onde os considerava menos apáticos, se comparados com os da Alemanha (Weltpresse 1947; Wiener Kurier 1947). Durante os meses de dezembro de 1947 e janeiro de 1948, percorreu, com o cônsul Antonio 
Houaiss, mais de 5.000 quilômetros, tendo visitado acampamentos em Frankfurt, Munique, Heidelberg, Salzburg, Viena, Graz e Innsbruck. Em entrevista concedida após sua missão de avaliação, externou tanto suas impressōes, marcadamente positivas, destacando a satisfação com as qualidades essenciais dos refugiados e deslocados - entre elas a de não serem comunistas -, quanto a "tendência desfavorável [no Brasil] à imigração de pessoas deslocadas”, que se devia à propaganda e ao 'preconceito de isolacionismo" (Journal de Genève 1948a). Contudo, asseverou "não acredit[ar] que o Brasil perderá a ocasião de provar mais uma vez seu espírito de cooperação e seus sentimentos humanitários", não obstante tratar-se de uma "decisão conforme aos interesses no nosso país” (Journal de Genève 1948a).

Em fins de janeiro de 1948, o delegado brasileiro já tornava públicas algumas das cláusulas que seriam objeto de um acordo entre o Brasil e a Comissão Preparatória, em particular quanto à contribuição daquele a esta e ao estabelecimento de uma comissão mista (Journal de Genève 1948b). Após suas viagens pelos acampamentos de refugiados e deslocados na Europa, o delegado brasileiro foi ao seu país com o objetivo de tentar diminuir a resistência que havia, motivada pela propaganda dirigida contra a recepção de imigrantes. Constatou ter sido criada, finalmente, uma opinião favorável, justificada também pela presença de um representante da Comissão Preparatória, sr. Pierre Boal, que afirmou ser o Brasil um dos pioneiros a oferecer possibilidades de imigração e colonização quase ilimitadas (La Tribune de Genève 1948).

Como a Comissão Preparatória não absorvera todas as responsabilidades constantes nos dispositivos do Acordo Brasil-Comitê Intergovernamental, que não fora completamente implementado, por não ter logrado completar a cota de 5.000 refugiados e deslocados, ${ }^{6}$ conclui-se, a 30 de abril de 1948, o Acordo Administrativo entre o Governo dos Estados Unidos do Brasil e a Comissão Preparatória da Organização Internacional

\footnotetext{
${ }^{5}$ Para os comentários do ministro Lobo quanto à ordem, aos sentimentos religiosos e à disciplina dos refugiados e deslocados, v. Le Courrier 1948.

${ }^{6}$ Durante o período de 1 de julho de 1947 a 29 de fevereiro de 1948, dos 125.374 refugiados e deslocados reassentados, tão-só 2.511 haviam chegado ao Brasil; cf. Muniz 1948: 2. A cifra acolhida no Brasil era inferior, portanto, à que recebera guarida na Argentina (12.163) e na Venezuela (5.666); cf. Lobo 1948: 4.
} 
de Refugiados [Acordo Brasil-Comissão Preparatória]. Simultaneamente à sua conclusão, eram trocadas, entre o secretário-geral do Itamaraty e o representante especial do secretário executivo da Comissão Preparatória da OIR, notas complementares pelas quais se instituiu um regime financeiro para a execução do Acordo Brasil-Comissão Preparatória (Accioly 1948a: 1; Accioly 1948b: 1; Boal 1948a: 2; Boal 1948b: 1).

O Acordo Brasil-Comissão Preparatória substituiu o Acordo BrasilComitê Intergovernamental e dispôs, inter alia, sobre a criação de uma Comissão Mista Brasil-OIR; sobre o reconhecimento oficial, pelo Brasil, da existência da OIR e de um estatuto condigno, na base de reciprocidade, para os representantes mais graduados; o recebimento, encaminhamento e colocação, a cargo do Brasil, do resto dos refugiados e deslocados cuja entrada fora prevista pelo Acordo Brasil-Comitê Intergovernamental, bem como de outro contingente de 1.000 famílias (5.000 pessoas); transporte dos mesmos até o Brasil, a cargo da Comissão Preparatória; livre direito de recrutamento dos imigrantes pelo Brasil, com o auxílio dos serviços especializados da OIR; e cláusula particular que permitia ao Brasil o aproveitamento de $15 \%$ do frete dos navios-transportes de refugiados e deslocados destinados ao Brasil para sua imigração particular, promovida em virtude de outros acordos.

Um dos dispositivos mais avançados foi o relativo à possibilidade de os chefes de família poderem ser acompanhados por todos os membros de sua família mais próximos e que viviam em sua companhia. O Brasil foi um dos primeiros países a aceitar o reassentamento de famílias inteiras, tendo criticado os sistemas de recrutamento que rompiam os vínculos familiares assim como rejeitado o tratamento dos refugiados e deslocados como "mercadoria" (The New York Times, 1948). No texto do referido instrumento legal chegou a ser vislumbrada a conclusão de um ajuste relativo à imigração de parentes de pessoas já instaladas no Brasil, o que nunca chegou a ocorrer. Notava-se já àquela época a abertura do país ao princípio da reunião familiar, de base, notadamente, humanitária.

Não obstante o Acordo Brasil-Comissão Preparatória ter entrado em vigor no plano internacional na data de sua assinatura e ter sido inicialmente válido até 31 de dezembro de 1948, podendo ser renovado sucessivas vezes - com efeito, o Acordo foi renovado, tacitamente, haja vista a data tardia de sua implementação, infra (Braga \& Stansby 1949: 
3) -, sua implementação doméstica só foi possível após a publicação do Decreto no 25.796 , de promulgação, que teve lugar mais de seis meses após sua assinatura e um mês e meio antes do término da validade inicialmente prevista. A execução do Acordo Brasil-Comissão Preparatória tardou tanto devido "à resistência que, ostensiva ou silenciosamente, a recepção dos 'refugiados' depara, já não se diga na opinião, mas nalguns representantes da administração pública", que consideravam o estabelecimento da Comissão Mista Brasil-OIR um "atentado” à soberania brasileira (Lobo 1948: 12-3) ou, na realidade, uma ameaça a determinadas instâncias que se arrogavam a totalidade das iniciativas e competências, comprometidas - julgavam - pelas atribuiçóes administrativas que a referida Comissão viria a ter.

Foi, assim, só a 15 de dezembro de 1948 que a Comissão Mista Brasil-OIR foi instalada. Tendo tido suas sessões plenárias secretariadas pelo representante do Itamaraty, Miguel Paranhos do Rio Branco, a Comissão Mista Brasil-OIR auxiliou o Departamento Nacional de Imigração e outros órgãos correlatos nas atividades de recepção; reclassificação das profissões; fichamento; encaminhamento; assistência; serviço de preservação de bagagens; propaganda; e ajuda financeira. Para as questôes que pediam soluçôes locais e imediatas, criaram-se várias subdelegacias, a saber: em São Paulo, Rio Grande do Sul, Rio de Janeiro, Paraná, Goiás, Santa Catarina e Bahia. Uma das atividades mais interessantes da Comissão Mista Brasil-OIR foi a relativa à propaganda: por intermédio da imprensa de todo o país, da radiodifusão e de publicações especializadas, como o folheto Dados sobre a Comissão Mista Brasil - O.I.R., buscou-se esclarecer aos empregadores brasileiros e às autoridades, em geral, a importância e os benefícios resultantes da vinda e contratação de imigrantes.

Foi no marco da Comissão Mista Brasil-OIR que o Brasil, finalmente, passou a cumprir o acordado com os organismos internacionais e a receber fluxos maiores de refugiados e deslocados. Alcançou-se, entre dezembro de 1948 e agosto de 1949, a cifra de 14.016 pessoas, recepcionadas e encaminhadas para vários estados, encabeçando a lista de 28 nacionalidades os poloneses (5.468) e os húngaros (1.450) (Rio Branco 1949c: 9-12). Não obstante o resultado positivo - ao menos à luz do que fora logrado ao longo de 1946 e 1947 -, só obtido com o 
estabelecimento da Comissão Mista Brasil-OIR, em novembro de 1949 o Itamaraty era informado, mediante ofício, sobre a decisão de se encerrar, a 15 de dezembro de 1949, as atividades da referida comissão, incluindo as subdelegacias, seus centros de recepção, o escritório de colocação, o secretariado central, bem como os demais serviços. A antecipação desta medida foi determinada por razões de ordem financeira, ${ }^{7}$ da leitura do referido ofício, cabe ressaltar, transparece um certo desapontamento resultante da apatia e morosidade administrativa demonstradas pelas autoridades brasileiras.

\section{Do (não-)Comprometimento do Brasil com a Constituição da OIR}

Desde a assinatura da Constituição da OIR, a $1^{\circ}$ de abril de 1947 (supra), as autoridades brasileiras passaram a considerar, de forma mais concreta, o comprometimento jurídico, mediante depósito do instrumento de ratificação, que tornaria o Brasil Estado-membro daquele organismo internacional. O "alto teor político" das atividades da OIR não passava despercebido, contudo se tentava destacar, sob o ponto de vista meramente imigratório, o "elevado valor" dos refugiados e deslocados, assim como o interesse imediato do Brasil em fomentar o ingresso destes, posto cuidar-se de um "mercado migratório de alto valor intrínseco e sobremaneira momentâneo", que possibilitava "receber, em igualdade de despesas, (...) um volume maior de emigrantes, em condições de colocação melhores, pelo canal da OIR do que por qualquer outro meio" (Rio Branco 1947: 11).

Com data de 17 de novembro de 1947, seguiu para o presidente da República a Exposição de Motivos sobre o comprometimento do Brasil com a OIR. Esse documento indicava a importância da ratificação brasileira para a questão orgânica da OIR, ratificação esta que poderia influenciar favoravelmente a de outros países da América Latina. Deveria

\footnotetext{
${ }^{7}$ Embora "disp[usesse] a Comissão de verba suficiente para continuar a manter-se, não a t[inha] a seu alcance por achar-se representada pelos adiantamentos, ainda não reembolsados, feitos a Autoridades Federais e, em um ou dois casos, a Autoridades Estaduais, mediante conhecimento e aprovação da Presidência do Conselho de Imigração e Colonização", e era levada a "[r] econhece[r] não ser provável, a breve prazo, o reembolso das importâncias adiantadas"; v. Braga \& Stansby 1949: 1-2.
} 
o Brasil mover-se, asseverava o documento, tendo em vista o "aspecto de cooperação internacional nítido [e o] imperativo humanitário, que não excluem, por parte dos países que colaboram na solução do problema, a preservação das próprias conveniências essenciais" (CIC 1947: 5).

A Exposição de Motivos sugeria que o Brasil se comprometesse pagando o que lhe cabia da parte administrativa, e fazendo dois acordos, um para o pagamento das despesas de execução e outro para um plano de colonização em grande escala (CIC 1947: 8). Dentre os vários benefícios inerentes e resultantes do comprometimento brasileiro, destacaram-se, inter alia, no referido documento, a variedade profissional; uma corrente migratória já formada, suscetível de aperfeiçoamento gradual em sua organização e que dispunha de elementos de transporte; a aplicação de parte do crédito concedido no próprio país, inclusive na própria colonização; a melhoria das safras e da produção em geral; a possibilidade da implantação de uma indústria de produtos de economia doméstica dos refugiados e deslocados, de que a OIR seria um dos melhores clientes; a possibilidade de se exportar para a OIR; a possibilidade de completar a imigração de recrutamento livre; a possibilidade de aproveitar, periodicamente, uma porcentagem de praça nos transportes para a imigração de livre recrutamento; e, por fim, a oportunidade de promover uma colonização em apreciável escala, no interior do país, mediante planos técnicos conjuntos, sendo seu financiamento já incluído, em parte, nas contribuiçóes do Brasil (CIC 1947: 9-10).

Após o estudo da referida Exposição de Motivos, a Presidência da República enviou a Constituição da OIR ao Congresso, visando a obter a aprovação parlamentar necessária ao comprometimento, mediante ratificação, do Brasil com a Constituição da OIR. Enquanto deputados e senadores avaliavam a conveniência de o Brasil tornar-se Estado-membro da OIR, dois fatos importantes tinham lugar: firmava-se, em abril de 1948, o Acordo Brasil-Comissão Preparatória; e a OIR era estabelecida, após o depósito do $15^{\circ}$ instrumento de ratificação, em agosto de 1948 (supra). Ambos os eventos, naturalmente, imprimiram maior pressão para que o Brasil se tornasse Estado-parte da Constituição da OIR.

Consideraçóes financeiras, contudo, impediam o comprometimento brasileiro. Ademais da quota anual de administração, no valor de U\$ 88.000,00, a quota de execução que caberia Brasil era de 
U\$ 2.300.000,00 anuais. Ante a recusa brasileira em colaborar com tal montante, concordou a OIR em que esta rubrica fosse integralmente empregada em imigração para o Brasil. Contudo, e como bem esclarecido em Ajuda-Memória preparada pelo Serviço de Informações do Itamaraty, apresentava-se um problema de financiamento, estimado em algumas centenas de milhões de cruzeiros, a ser utilizado em um prazo de três anos e indispensável para o estabelecimento de núcleos coloniais. Consultado o ministro da Fazenda pelo presidente da República, na presença dos ministros interessados e do presidente do CIC, foi ele de opinião que o orçamento federal não comportava despesa desse vulto nem era suscetível de ser aumentado (SI/MRE 1949: 3). Só por meio de um empréstimo externo, cujo serviço de juros e amortização estivesse ao alcance do Brasil, poderia haver comprometimento com a Constituição da OIR.

As dificuldades encontradas para a obtenção do empréstimo internacional fizeram com que várias instâncias se movimentassem no sentido de avançar o comprometimento do Brasil com a OIR. A delegação brasileira junto à OIR, em nome de seu representante, ministro Helio Lobo, indicava em outubro de 1948, pouco após o estabelecimento deste organismo especializado, que "coibir-se o Brasil, à ratificação ainda que o fizesse premido pelo imperativo categórico da ausência de recursos financeiros, redundaria em descrédito para nosso país", e, como conseqüência, solicitava que a embaixada brasileira em Washington se empenhasse em obter um pronunciamento categórico do governo estadunidense quanto à perspectiva de abertura de crédito (Machado 1948: 2-3). As negociações quanto ao empréstimo continuavam, mas não avançavam.

Conseqüentemente, não obstante o Executivo já ter enviado a Constituição da OIR à aprovação do Congresso, o "Itamaraty se interessou para que o andamento do projeto se retardasse até o desfecho das negociações para o empréstimo" (SI/MRE 1949: 4), sem o qual o Brasil não poderia se associar àquele organismo com a segurança de cumprir as obrigações financeiras daí resultantes. Foi surpresa geral, portanto, quando em 7 de dezembro de 1948, mediante o Decreto Legislativo $\mathrm{n}^{\mathrm{o}} 42$, o Congresso deu sua aprovação à Constituição da OIR. Estando com o presidente de República a discricionariedade, a partir da aprovação parlamentar, de assinar o instrumento de ratificação 
que tornaria o Brasil Estado-membro da OIR, optou o Executivo por suspender as formalidades de comprometimento até o desfecho das negociações relativas ao empréstimo necessário. Só que este não veio e, portanto, o Brasil jamais ratificou a Constituição da OIR, não obstante a aprovação parlamentar.

Durante o ano de 1949, ao longo do qual não faltaram moções que buscassem o comprometimento brasileiro com a Carta constitutiva da OIR (Braga 1949: 1-14; Rio Branco 1949b: 1-5), a vinda de refugiados e deslocados deu-se no marco do Acordo Brasil-Comissão Preparatória, renovado, tacitamente, a 31 de dezembro de 1948. Contudo, com o término das atividades da Comissão Mista Brasil-OIR, a 15 de dezembro de 1949, fazia-se necessário um novo marco que concedesse apoio jurídico e proporcionasse a operacionalização da seleção, transporte, recebimento e colocação de refugiados e deslocados.

\section{Tentativa de Acordo Bilateral OIR-Estado de São Paulo \& Término das Atividades}

Menos de um ano após seu estabelecimento, já era discutido, na III Sessão Extraordinária de seu Conselho Geral, realizada de 28 de junho a 8 de julho de 1949, o término das atividades da OIR, previsto para meado de 1950. Paralelamente ao fim da OIR, já se começava a vislumbrar, no Ecosoc, "um plano no qual constasse a criação no quadro das Naçóes Unidas de um organismo que permit[isse] à ONU incumbirse da proteção internacional de refugiados e funções conexas", sendo as possibilidades então apresentadas "a criação de um Alto-Comissariado sob controle das Naçôes Unidas ou a criação de um serviço no quadro do Secretariado das Nações Unidas"(Lobo 1949: 2). Conseqüentemente, com a perspectiva de fechamento da OIR, poucas foram no Brasil as iniciativas, em 1950, relacionadas à migração de refugiados e deslocados. Como alternativa, e já resignado em não poder se tornar membro da OIR por razóes financeiras, propôs o Brasil resolução para que se fizesse um estudo sobre as possibilidades de financiamento internacional para a emigração européia que se dirigisse a países insuficientemente habitados (Souza-Bandeira 1950: 3).

A extensão da existência da OIR até o início de 1952 chegou a propiciar, ainda, a tentativa de um acordo a ser firmado diretamente 
com o Estado de São Paulo. Os primeiros anos da República viram um incremento significativo na imigração para aquele estado. Como a Constituição de 1891 permitia aos estados legislar, com inteira liberdade, sobre imigração, São Paulo aproveitou para aumentar o fluxo a ele dirigido: de 9,2\% do total de imigrantes entrados no país em 1878, veio a receber 67\% em 1897 e 84,1\% em 1901 (Ribeiro 1943: 55). Em 1947 aquele estado informava estar habilitado a receber, para trabalhos agrícolas, mais de 5 mil famílias, totalizando cerca de 25 mil indivíduos (Rio Branco 1947: 6).

Já estando claro que o Governo Federal não viria a comprometer o país com a Constituição da OIR, foram feitas gestôes no sentido de se aprovar, no CIC, um acordo entre o Governo do Estado de São Paulo e a OIR, mediante o qual a OIR se responsabilizaria pelo envio de 5.000 refugiados e deslocados, em contingentes de oitocentas pessoas, ao porto de Santos, aonde chegariam com intervalos de quarenta dias. Após a aprovação, em julho de 1950, do referido acordo, foi ele encaminhado, a 2 de agosto de 1950, com a Exposição de Motivos, ao presidente da República (Souza 1951). Por "não [ter] havi[do] reconhecimento, na esfera federal, das vantagens da imigração para São Paulo nem cooperação do Governo da União com o do Estado" (Vasconcellos 1951: 1), esperouse o início da gestão de Getúlio Vargas, em 1951, para se avançar com o acordo entre a OIR e o Estado de São Paulo.

Aspectos jurídicos impediram, contudo, que o acordo fosse firmado. Não obstante o CIC ter-se posicionado pela constitucionalidade do acordo, a consultoria jurídica do Itamaraty afirmou que "um Estado Federado não [pode] agir nas órbitas internacionais, [nem] assumir compromissos de feição internacional, [nem tampouco] tratar e obrigarse com uma organização internacional”, e que, portanto, "[s]omente a União (...) pode manter relações de qualquer espécie, contratuais ou não, com alguma organização internacional" (Carneiro 1967b: 483-4).

No início de 1952 o chefe de missão da OIR no Brasil, que cobria também outros países, escrevia ao ministro de Estado das Relações Exteriores informando tanto o fechamento do escritório no Rio de Janeiro, a 31 de janeiro, quanto a cifra de 29.000 refugiados e deslocados encaminhados ao Brasil ao longo das atividades da OIR neste país (Stansby 1952). Pouco depois, e com o término das operações da OIR, era a vez de seu diretor-geral, em ofício aparentemente padrão, agradecer 
a compreensão, colaboração e esforços no sentido de organizar a recepção e a colocação dos refugiados e deslocados no Brasil (Kingsley 1952).

\section{Considerações Finais}

A repatriação, solução ideal repetida com insistência no texto da Constituição da OIR, graças aos países do Bloco do Leste, não chegou a ser utilizada em grande escala. Do "milhão restante", somente 73.000 pessoas (Moussalli 1992: 85; Chen 1973: 165; Ruiz de Santiago 1989: 236) foram repatriadas, o que não chegou a representar $6 \%$ do total de indivíduos sob o mandato da OIR (Plender 1988: 400; Stoessinger 1956: 111). Por sua vez, pouco mais de 1.000 .000 de refugiados e deslocados (Cuadra 1970: 151; Moussalli 1992: 85; UNHCR 1972: 26; Heuven Goedhart 1953: 277; Chen 1973: 165), mais precisamente 1.038.750 pessoas (IRO 1951) foram reassentadas em 65 países, a maioria fora do continente europeu.

A inexistência de uma repatriação em massa e o fato de quase meio milhão de refugiados ter passado para a proteção do Acnur, quando da extinção da OIR, não significa dizer que o mandato da OIR não foi cumprido. $\mathrm{O}$ pouco expressivo número de repatriações não foi resultado de incapacidade operacional deste organismo, mas sim de considerações políticas resultantes da Guerra Fria.

O repúdio da URSS à política adotada na OIR fez com que esta tivesse que escolher entre, por um lado, a universalidade e a paralisia, e, por outro, a seletividade quanto aos seus Estados-membro e a eficácia no desempenho de suas funções. Ao escolher a segunda das opçôes, os problemas tiveram de ser resolvidos de uma forma tipicamente ocidental, o que proporcionou aos refugiados uma considerável liberdade de escolha. Contudo, a generosidade dos Estados Unidos - que se comprometeram a receber $40 \%$ das pessoas sob o mandato da OIR e a prover $60 \%$ de seu orçamento $^{8}$ - já fora provocada com a insistência dos países do Bloco do Leste no que respeitava à repatriação forçada. Diante disto, os Estados Unidos optaram por não mais apoiar um organismo que incluísse entre

\footnotetext{
${ }^{8}$ A Constituição da OIR, em seu Anexo II, estipulava, não obstante, que a contribuição dos Estados Unidos quanto às despesas administrativas e às operacionais deviam ser, respectivamente, $39,89 \%$ e $45,75 \%$.
} 
seus membros Estados que não estivessem de acordo com o movimento internacional livre de pessoas, o que levou à substituição da OIR pelo Acnur. ${ }^{9}$ Isso deve ser considerado quando se proceder à avaliação da OIR na execução de seu mandato.

A participação do Brasil nos esforços da OIR foi deveras particular. Os articuladores da política exterior brasileira notaram a necessidade de um envolvimento nas iniciativas onusianas, especialmente naquelas de interesse das potências ocidentais. Os discursos dos representantes brasileiros, destarte, refletiam o que parecia ser um compromisso com a OIR - quando, na realidade, eram tão-somente a expressão de suas boas-intençōes. O efeito ornamental do desempenho diplomático brasileiro logo se notou: o Brasil angariou considerável prestígio, o que lhe proporcionou, em deferência especial, assento no Conselho Geral da OIR, pois "tudo indicava em Genebra que o nosso país não faltaria com a ratificação e viria tomar parte efetiva no Conselho Geral e (...) no Comitê Executivo, para ter papel na política da Organização" (Lobo 1948: 10).

A recepção de refugiados e deslocados não era só interessante para a execução da política exterior brasileira. Outro motivo que levara o Brasil a buscar a imigração daqueles que não desejavam regressar aos seus países de origem após a Segunda Grande Guerra era a conveniente convergência de sentimentos e princípios humanitários - não externados no período entreguerras, ao menos vis-à-vis os refugiados que recorreram à proteção internacional àquela época -, com a oportunidade de receber mão-de-obra qualificada que viesse a suprir a demanda doméstica. Esta demanda era evidente, em especial após tantos anos de política imigratória restritiva, e os ganhos econômicos do Brasil com a imigração eram óbvios (Avila 1954).

Apesar de ser de interesse da política externa brasileira, da política de imigração desenvolvida no pós-guerra e da satisfação do imperativo humanitário, no qual aparentemente estribavam-se as autoridades brasileiras, o Brasil só recebeu 29.000, dos mais de 1.000 .000 de

\footnotetext{
${ }^{9}$ A URSS manteve-se o máximo que pôde afastada das atividades executadas pelo Acnur, não tendo nunca se comprometido com a Convenção Relativa ao Estatuto dos Refugiados, de 28 de julho de 1951, nem tampouco com o Protocolo Relativo ao Estatuto dos Refugiados, de 31 de janeiro de 1967.
} 
refugiados e deslocados reassentados pela OIR, e não se tornou Estadomembro da OIR mediante comprometimento com sua Constituição.

A análise das fontes primárias e da bibliografia pesquisadas leva à conclusão de que houve uma confluência infeliz de deficiências as quais impossibilitaram que o Brasil participasse, de forma coerente, das atividades da OIR. Essas deficiências eram de ordem conjuntural e estrutural - tendo sido ambas responsáveis pelo fato de o Brasil não ter logrado o empréstimo que o tornaria apto a contribuir com sua cota junto àquele organismo.

Quanto às deficiências de ordem estrutural, destacam-se falhas burocráticas e morosidade administrativa, como, inter alia, a ausência tanto de um cadastro da mão-de-obra necessária quanto de critérios a serem aplicados na seleção dos refugiados e deslocados; a demora da publicação do decreto de promulgação do Acordo Brasil-Comissão Preparatória; e a ausência de reembolso, por parte das autoridades federais e estaduais, de adiantamentos feitos pela Comissão Mista Brasil-OIR, o que resultou no término das atividades desta.

No que respeita às deficiências de ordem conjuntural, houve propaganda desfavorável e aversão da opinião pública, acentuadas por racismo e resistência, ostensiva ou silenciosa, dos representantes da administração pública, que viam nas atividades da OIR e de suas instâncias domésticas ameaça à soberania brasileira e às suas competências burocráticas.

Na Exposição de Motivos enviada ao presidente da República, que estudava a conveniência do comprometimento do Brasil com a Constituição da OIR, afirmou-se que "[a]s questôes de ocasião, celeridade sem prejuízo do método, continuidade de ação, planejamentos previamente meditados e execução firme, constituem os fatores imprescindíveis de êxito, que, esquecidos, no todo ou em parte, produzem insucessos periódicos e parciais, preparando o fracasso total de uma empresa" (CIC 1947: 11). Na ocasião que se apresentou ao Brasil, não houve celeridade e continuidade de ação, nem tampouco planejamento e execução firme. Confia-se que as deficiências estruturais e conjunturais existentes no passado estejam e continuem sendo levadas em consideração, como lição, ao se desenhar e implementar os projetos de reassentamento que o governo brasileiro se propõe a levar a cabo, na hora atual, 
tendo-se sempre presente o imperativo humanitário que deve nortear, primordialmente, toda e qualquer ação em favor dos refugiados.

Recebido em 12 de agosto de 2004 Aprovado em 27 de abril de 2005

\section{Referências Bibliográficas}

\section{Fontes Primárias - instrumentos jurídicos}

BRASIL. Decreto n. 25.796, de 10 de novembro de 1948. Diário Oficial da União [DOU], p. 16-389, 17 de novembro de 1948.

. Decreto n. 38.018, de 7.out.1955. DOU, p. 19-06512, out, 1955.

. Decreto Legislativo n· 21, de 22 de julho de 1949. Diário do Congresso Nacional [DCN], seção 1, p. 6-413, 26 de julho de 1949.

. Decreto Legislativo $\mathrm{n} \cdot 42$, de 7 de dezembro de 1948. DCN, seção 1 , p.17-881, 15 de dezembro de 1948.

1924. "Arrangement Relating to the Issue of Identity Certificates to Russian and Armenian Refugees, supplementing and amending the previous Arrangements dated July 5, 1922, and May 31, 1924”, 89 League of Nations Treaty Series (1929), p. 47-52.

1946. "Agreement on Interim Measures to be taken in Respect of Refugees and Displaced Persons", 18 United Nations Treaty Series [UNTS] (1948), p. 122-123.

1946. "Agreement Relating to the Issue of a Travel Document to Refugees who are the Concern of the Intergovernmental Committee on Refugees", 11 UNTS (1947), p. 73-105.

1946. "Constitution of the International Refugee Organization", 18 UNTS (1948), p. 3-23.

1947. "Agreement between the PCIRO and UNRRA". In: L.W. Holborn, The International Refugee Organization: a specialized agency of the United Nations its history and work (1946-1952), London/New York: Oxford University Press, 1956, p. 592-594. 
1947. "Agreement between the IGCR and the PCIRO".In: L.W. Holborn, ibid., p. 591 e 592.

1948. "Acordo Administrativo entre o Governo dos Estados Unidos do Brasil e a Comissão Preparatória da Organização Internacional de Refugiados". In: Estrangeiros: Legislação - de 1940 a 1949. Vol. II, Rio de Janeiro, Ministério da Justiça e Negócios Estrangeiros, 1950, p. 697-702.

1951. "Convention Relating to the International Status of Refugees", 189 UNTS (1954), p. 137-221.

1953. "Constitution of the Intergovernmental Committee for European Migration (with annex)”, 207 UNTS (1955), p. 213-225.

1967. "Protocol Relating to the Status of Refugees", 606 UNTS (1967), p. 268-277.

\section{Fontes Primárias - artigos de jornal}

Le problème des réfugiés - uniquement, un peut de bonne volonté de la part de chaque nation, nous dit S.E. M. Helio Lobo, délégué du Brésil à l'O.I.R. (sic). Journal de Genève, 5 jan. 1948.

Pour le réétablissement en masse des réfugiés - Le Brésil fait le premier pas. Journal de Genève, 27 jan. 1948.

Pour les réfugies - Le Plan Lobo.: La Tribune de Genève, 5 de fevereiro de 1948.

LACERDA, Carlos. Abra-se, afinal, alguma coisa. A Tribuna da Imprensa, 14 dez.1947.

CPOIR, Commission préparatoire de l'Organization internationale des réfugiés. Le Courrier, 25 fev. 1948.

QUEIROZ, Raquel de. Indesejáveis. Diário de Notícias, 14 set. 1947.

REGO, José Lins do. Sobre a Imigração dos Deslocados. O Globo, 26 nov. 1947.

Brazil will admit refugee families. The New York Times, 9 maio. 1948.

Erster Transport von Versetzten Personen nach Brasilien - Minister Lobo erklärt: 'D.P.-Tragödie, die grösste der Welt'. Weltpresse, 28 nov. 1947.

Erster DP-Transport nach Brasilien im Jänner 1948.: Wiener Kurier, 28 nov. 1947. 
Fontes Primárias - ajuda-memórias, atas, cartas, estudos, ofícios, memorandos, pareceres jurídicos e relatórios

ACCIOLY, Hildebrando (1948a) a BOAL, Pierre de Lagarde, carta, 30. abr. 1948, 1p.,

Arquivo Histórico do Itamaraty/MRE, Brasília-DF [AHI/DF], classe 601.34.

ACCIOLY, H. (1948b) a BOAL, P. de L. de, nota, 30.abr.1948, 1p., AHI/DF, classe 601.34 .

BOAL, Pierre de Lagarde (1948a) a ACCIOlY, H., carta, Rio de Janeiro, 30.abr.1948, 2 p., AHI/DF, classe 601.34.

BOAL, P. de L. (1948b) a ACCIOLY, H., nota, Rio de Janeiro, 30.abr.1948, 1p., AHI/DF, classe 601.34.

BRAGA, Odilon (1949) a DUTRA, Eurico Gaspar, ofício, Rio de Janeiro, 4.fev.1949, 14p., AHI/DF, classe 601.34.

BRAGA, O. \& STANSBY, Dumon (1949) a FERnANDES, Raul, ofício, CM/272, Rio de Janeiro, 16.nov.1949, 4p., AHI/DF, classe 601.34.

CARNEIRO, Levi (1967a) "[Parecer] Condição de refugiados e apátridas. Competência para legalização de documentos referentes à sua vida civil”, de 5.dez.1951. In: Pareceres dos Consultores Jurídicos do MRE (1946-1951), Rio de Janeiro, Seção de Publicações/MRE, p. 575.

CARNEIRO, L. (1967b) “[Parecer SJ/1.355] Acordo de um Estado Federado com a Organização Internacional de Refugiados, artigo $5^{\circ} \mathrm{I}$, da Constituição Federal", de 5.mar.1951, in Pareceres dos Consultores..., supra, p. 483 e 484.

CARVALHO, Rui de (1947a) a LATOUR, Jorge, Memorando, $\mathrm{n}^{\circ} 1$, Rio de Janeiro, 1.jul.1947, 2p., AHI/DF, classe 601.34.

CARVALHO, R. de (1947b) a LATOUR, J., Memorando urgente, ${ }^{\circ} 37$, Rio de Janeiro, 18.jul.1947, 3p., AHI/DF, classe 601.34.

CHERMONT, Jayme Sloan (1952) a FONTOURA, João Neves da, ofício, Londres, 23.set.1952, 1p., AHI/DF, classe 601.34.

CIC [Conselho de Imigração e Colonização] (1947) Estudo sobre a conveniência da ratificação da Constituição da O.I.R pelo Governo Brasileiro. Rio de Janeiro, 17.nov.1947, 12p., AHI/DF, classe 601.34.

CIC (1955) Ata da 692 a sessão, de 8.out.1946, in DOU, 12.out.1955, p. 29-30. 
Exposé (1946a) du Delegué du Brésil - Comité Special des Refugiés et Personnes Deplacées, UN/ECOSOC doc. E/REF/45, Londres, 26 abr.1946, 2p., AHI/ DF, classe 601.34.

Exposé (1946b) du Delegué du Brésil - Comité Special des Refugiés et Personnes Deplacées - Sous-Comité des Definitions, UN/ECosoc doc. E/REF/FACTFINDING/26, Londres, 13 maio.1946, 4p., AHI/DF, classe 601.34.

IRO (1951) IRO: Statistical Report, Geneva, IRO, 31 dez.1951.

KINGSLEY, J. Donald (1952) a FONTOURA João Neves da, ofício, Genebra, 8.fev.1952, 1p., AHI/DF, classe 601.34.

LOBO, Helio (1949) a Fernandes, Raul, ofício, Del.Bras.OIR/Genebra 1949/69, Genebra, 30 set.1949, 4p., AHI/DF, classe 601.34.

MACHADO, Eberaldo Abilio Telles (1948) ao chefe da DAI/MRE, memorando, Genebra, $1^{\circ}$ out.1948, 3p., AHI/DF, classe 601.34.

MUNIZ, João Carlos (1948) a Fernandes, Raul, ofício, Del.Bras. NU/105/1948/2, Nova York, 22 abr.1948, 2p., AHI/DF, classe 601.34.

Renseignements (1946) Fournis par la Delegation du Brésil - Comité Special des Refugiés et Personnes Deplacées - Sous-Comité de Documentation, UN/Ecosoc doc E/REF/FACT-FINDING/14, Londres, 6 maio,1946, 8p., AHI/DF, classe 601.34 .

RIO BRANCO, João Paulo do (1947) a LATOUR, Jorge, memorando reservado, COO/601.34(00), Rio de Janeiro, 10 nov.1947, 12p., AHI/DF, classe 601.34 .

RIO BRANCO, J. P. do (1949a) Projeto de Instruções Gerais para a Imigração de Refugiados, Rio de Janeiro, 15 mar.1949, 8p., AHI/DF, classe 604.31.

RIO BRANCO, Miguel Paranhos do (1949b) a ARRUDA, Orlando, ofício, Rio de Janeiro, 20 out.1949, 5p., AHI/DF, classe 601.34.

RIO BRANCO, M. P. do. (1949c) Anexo I - A Organização Internacional para os Refugiados. Sua Obra no Mundo - No Brasil, Rio de Janeiro, 15 set.1949, 12p., Arquivo Histórico do Itamaraty/MRE em Brasília-DF [AHI/DF], classe 601.34 .

SI/MRE (1949) [Brasil] Ministério das Relações Exteriores. Serviço de Informações, Ajuda-Memória, Rio de Janeiro, 26 ago.1949, 5p., AHI/DF, classe 601.34 . 
SOUZA, Odete de Carvalho e (1951) ao Ministro de Estado das Relações Exteriores, ofício, Rio de Janeiro, 26 fev.1951, 4p., AHI/DF, classe 601.34.

SOUZA-BANDEIRA, Octávio de (1950) discurso em sessão plenária do Ecosoc, Del.Bras./Genebra/Diversos/1950/N. 32/Anexo n. 3, 20 jul.1950, 3p., AHI/DF, classe 601.34.

STANSBY, Dumon (1952) a FONTOURA, João Neves da, ofício, G-2067, Rio de Janeiro, 7 jan.1952, 1p., AHI/DF, classe 601.34.

VASCONCELLOS, Henrique D. de (1951) ofício, 0203 - MRE/DPp/ SJ/601.34(04)/1951/Anexo n. 2, São Paulo, 26 fev.1951, 4p., AHI/DF, classe 601.34 .

\section{Fontes Secundarias - livros}

AVILA, F.B. de. Economic Impacts of Immigration - the Brazilian immigration problem. The Hague: Martinus Nijhoff, 1954.102p.

BOLESTA-KOZIEBRODZKI, L. Le Droit d'Asile. Leyde, Sythoff, 1962. 374p.

CHEN, S.S.-T. The Theory and Practice of International Organization. 2- ed., Hartford: Central Connecticut State College, 1973. 202p.

CUADRA, H. La Proyección Internacional de los Derechos Humanos. México, Instituto de Investigaciones Jurídicas/UNAM, 1970. 308p.

FISCHEL de Andrade, J.H. Direito Internacional dos Refugiados - evolução histórica (1921-1952). Rio de Janeiro, Renovar, 1966. 213p.

GRAHL-MADSEN, A. The Status of Refugees in International Law. Vol. I, Leyden, A.W. Sithoff, 1966. 499p.

GINESY, R. La Seconde Guerre Mondiale et les Déplacements de Populations: les organismes de protection. Paris: Pedone, 1948. 184p.

GOODWIN-GILL, G.S. The Refugee in International Law. 2 ed., Oxford: Claredon Press, 1996. 584p.

GORDENKER, L. Refugees in International Politics. New York: Columbia University Press, 1987. 227p.

HOLBORN, L.W. The International Refugee Organization: a specialized agency of the United Nations - its history and work (1946-1952). London/New York: Oxford University Press, 1956. 805p. 
NEIVA, A.H. Deslocados de Guerra - a verdade sobre sua seleção. Rio de Janeiro: Ed. A Noite, 1949. 301p.

PLENDER, R. International Migration Law. Dordrecht, Martinus Nijhoff, 1988. 587p.

STOESSINGER, J.G. The Refugee and the World Community. Minneapolis: University of Minnesota Press, 1956. 239p.

UNHCR A Mandate to Protect and Assist Refugees, Geneva, 1972. 136p.

YUNDT, K.W. Latin American States and Political Refugees.. Westport (Conn.)/ London:, Praeger, 1988. 236p.

\section{Fontes Secundárias - artigos e monografias}

AGA Khan, S. Legal Problems Relating to Refugees and Displaced Persons, 149(I). In: Recueil des Cours de l'Académie de Droit International [RCADI], p. 287-352.1976.

BALOGH, E. World Peace and the Refugee Problem, 75(II). In: RCADI, p. 363-507. 1949.

BERTONHA, J.F. O Brasil, os imigrantes italianos e a política externa fascista, 1922-1943, 40(2). Revista Brasileira de Politica Internacional, ano 46, v . 2. Brasília: Instituto Brasileiro de Relações Internacionais. 1997, p. 106-130.

FISCHEL DE ANDRADE, J.H. (1999). O Direito Internacional dos Refugiados em Perspectiva Histórica. In: A. Amaral Jr. \& C. Perrone-Moisés (orgs.), O Cinqüentenário da Declaração Universal dos Direitos do Homem. São Paulo: Edusp (Biblioteca EdUSP de Direito; 6). 1999, p. 75-120.

FISCHEL DE ANDRADE, J.H. \& MARCOLINI, A. A Política Brasileira de Proteção e de Reassentamento de Refugiados - breves comentários sobre suas principais características. Revista Brasileira de Política Internacional, ano 45, v. 1. Brasília: Instituto Brasileiro de Relações Internacionais. 2002, p. 168-176.

FOWLER, D.B. The Developing Jurisdiction of the United Nations High Commissioner for Refugees. Revue des Droits de l'Homme, 7(1). 1974, p. 119-144.

GINSBURGS, G. The Soviet Union and the Problem of Refugees and Displaced Persons 1917-1956. American Journal of International Law [AJIL], 51(2). 1957, p. 325-361. 
HARTLING, P. Concept and Definition of 'Refugee' - legal and humanitarian aspects, : Nordic Journal of International Law, 48(1-4). 1979, p. 125-138.

HATHAWAY, J.C. The Evolution of Refugee Status in International Law: 1920-1950. : International and Comparative Law Quarterly [ICLQ], 33(2). 1984, p. 348-380.

HEUVEN-GOEDHART, G.J. van. The Problem of Refugees. RCADI, 82(I). 1953, p. $261-371$

KRENZ, F.E. The Refugee as a Subject of International Law. ICLQ, 15(1). 1966, p. 90-116.

LESSER, J. Repensando a política imigratória brasileira na época Vargas. In: C.E. de A. Boucault \& T. Malatian (orgs.), Políticas migratórias: fronteiras dos direitos humanos no século XXI. Rio de Janeiro: Renovar. 2003, p. 277-287.

LOBO, H. (1948). A Organização Internacional para os Refugiados e o Brasil. Rio de Janeiro, Serviço de Publicações/ MRE. 1948, 13p.

MIAJA DE LA MUELA, A. Notas al Estatuto de los Refugiados. Revista Española de Derecho Internacional, 5(1). p. 133-156.

MOUSSALLI, M. The Evolving Functions of the Office of the United Nations High Commissioner for Refugees. In: V. Gowlland \& K. Samson (eds.), Problems and Prospects of Refugee Law (Colóquio de Genebra, 23-24.maio.1991). Genebra: Graduate Institute of International Studies. 1992, p. 81-104.

RSP. Nova Política Imigratória.: Revista do Serviço Público [RSP], III(3-4). 1947 , p. 57-70.

PERRUCHOUD, R. From the Intergovernmental Committee for European Migration to the International Organization for Migration. International Journal of Refugee Law, 1(4). 1989, p. 501-517.

REUT-NICOLUSSI, E. Displaced Persons and International Law. RCADI, 73(II). 1948, p. 1-68.

RIBEIRO, A.M. O Departamento Nacional de Imigração. In: RSP, II(2). 1943, p. 53-72.

RUIZ DE SANTIAGO, J. Derechos Humanos y Protección Internacional de los Refugiados. In: XV Curso de Derecho Internacional (1988), Washington: OEA. 1989. p. 217-268. 
SILVA, C.A. de S. e. O Brasil e os Organismos Internacionais para as Migrações. Revista Brasileira de Política Internacional, ano 1, v.1. Brasília: Instituto Brasileiro de Relações Internacionais. 1958, p. 144-155.

VULKAS, B. International Instruments dealing with the Status of Stateless Persons and Refugees. Revue Belgue de Droit International, 8(1). 1972, p. 143-175.

WEIS, P. (1954), The International Protection of Refugees, 48(2) AJIL, p. 193-221. ZANOTTI, I. (1948). Organização Internacional para os Refugiados (O.I.R.). RSP, II(3-4) 1954, p. 95-113.

\section{Resumo}

O artigo cuida da participação do Brasil, como Estado não-membro, nas atividades da Organização Internacional para os Refugiados (OIR). Após contextualizar do ponto de vista histórico, político e jurídico tanto o estabelecimento quanto o mandato da OIR, o autor analiza, com o uso de fontes primárias pesquisadas no Arquivo Histórico do Itamaraty, os bastidores, a implementação e os resultados da política exterior do Brasil no que respeita à proteção de refugiados no periodo que se estende de 1946 a 1952.

\section{Abstract}

The article deals with Brazilian participation, as a non-member State, in the activities of the International Refugee Organization (IRO). The author examines first the historical, political and legal context of both the establishment and the mandate of the IRO. He then uses primary sources researched at the Historical Archive of the Brazilian Ministry of Foreign Affairs to analyze the internal decision-making, enforcement and outcomes of Brazilian foreign policy relating to the protection of refugees between 1946 and 1952.

Palavras-chaves: Política Externa Brasileira; Organização Internacional para os Refugiados; Direito Internacional dos Refugiados; História Diplomática; História das Relações Internacionais; Direito Internacional Público.

Key words: Brazilian Foreign Policy; International Refugee Organization; International Refugee Law; Diplomatic History; History of International Relations; Public International Law. 